\title{
A tudományos szakfordítás empirikus kutatásának módszertani lehetőségeiről
}

\author{
Károly Krisztina \\ E-mail:karoly.krisztina@btk.elte.hu
}

\begin{abstract}
Kivonat: A kvantitatív és kvalitatív szemléletủ alkalmazott nyelvészeti kutatási módszerek, s velük együtt a fordítástudomány módszertani eszköztára gyors és eredményes fejlődésen ment keresztül az 1970-es évek óta. Tanulmányomban ennek a folyamatnak a legfontosabb eredményeibe nyújtok betekintést, kutatásmódszertani megközelítésben, a tudományos szakfordítás vizsgálatában alkalmazott kutatási módszerek területén. Az egyes módszertani megoldások lehetőségeit és alkalmazási módjait konkrét vizsgálatok példáin keresztül mutatom be és kitérek a kutatásokat és a korpuszépítést veszélyeztető megbízhatósági és hitelességi (validitási) problémákra és ezek lehetséges megoldásaira. Dolgozatom a bemutatottak nemzetközi és hazai implikációival zárul.
\end{abstract}

Kulcsszavak: tudományos szakfordítás, kutatási módszer, hitelesség, megbízhatóság

\section{Bevezetés}

A globalizációnak és az angol mint lingua franca gyors elterjedésének köszönhetően - egyéb területek mellett a tudomány és a felsőoktatás világában is - a tudományos szakfordítás iránti kutatói érdeklődés jelentős mértékben megnövekedett az elmúlt fél évszázadban. A kvantitatív és kvalitatív szemléletủ alkalmazott nyelvészeti kutatási módszerek, s velük együtt a fordítástudomány módszertani eszköztára - szoros együttmüködésben és kölcsönhatásban egymással - rendkívül gyors és eredményes fejlődésen ment keresztül az 1970-es évek óta.

Tanulmányomban ennek a folyamatnak a legfontosabb eredményeibe nyújtok betekintést, kutatás-módszertani megközelítésben, a tudományos szakfordítás vizsgálatában ez időszak során alkalmazott igen változatos kutatási módszerek áttekintésével. Az egyes módszertani megoldások lehetőségeit és alkalmazási

Hivatkozás: Károly K. 2020. A tudományos szakfordítás empirikus kutatásának módszertani lehetőségeiről. Forditástudomány 22. évf. 1. szám. 17-26.

DOI: https://doi.org/10.35924/fordtud.22.1.2 
módjait konkrét vizsgálatok példáin keresztül mutatom be. Tanulmányom második felében kitérek a kutatásokat és azon belül is a korpuszépítést veszélyeztető megbízhatósági és hitelességi (validitási) kérdésekre/problémákra, és ezek lehetséges megoldásaira is. Nem célom ugyanakkor a kutatási módszerek részletes bemutatása vagy - általában véve - a fordítástudományi vizsgálatok és a fordítási szöveg elemzés-módszertani kérdéseinek tárgyalása. Ezekről számos egyéb forrásban olvashatunk: a kvalitatív, kvantitatív és vegyes módszerü kutatások módszertanáról pl. Creswell (2009) vagy Denzin és Lincoln (1994/2000) könyvében; a fordítástudományi kutatások módszertani kérdéseiről pl. Klaudy (2007), valamint Williams és Chesterman (2002) munkájában; a fordítási szöveg elemzés-módszertani kérdéseiről Károly (2007: 252-263) könyvfejezetében.

\section{A tudományos szakfordítás kutatásában alkalmazott módszerek}

A tudományos szövegek fordításának sajátosságait feltáró munkák, Toury (1995) terminusával élve, elsősorban ún. célnyelvre orientált kontrasztív típusú elemzések. Arra vállalkoznak, hogy a fordított szövegeket olyan célnyelvi szövegekkel vessék össze, amelyek nem fordítás eredményeként keletkeztek, s az összehasonlítás alapján azonosítsák a fordítás egyedi sajátosságait. Munkájukhoz jellemzően a korpusznyelvészet módszereit és eszközeit használják (pl. Krein-Kühle 2011, Baumgarten, House és Probst 2004, Kemppanen 2004, Williams 2004, 2007, López-Arroyo és Méndez-Cendón 2007, López-Arroyo és Roberts 2017, Fuertes-Olivera és Pizarro-Sánchez 2002), melyeket esetenként dokumentumelemzéssel vagy a fordítókkal, a célnyelvi befogadókkal, fordító ügynökségek képviselöivel stb. készített interjúkkal egészítenek ki. E kutatások lehetővé teszik terjedelmes szövegeken vagy nagyméretủ adatbázisokon hipotézisek tesztelését a fordítástudomány számos területén, így többek között

- az univerzálékutatásban (pl. az explicitációs hipotézis vizsgálatában: Jawad, 2004),

- különféle lexikai elemek fordításával kapcsolatos kérdésekben (pl. Kemppanen (2004) kulcsszavak elemzésére vonatkozó tanulmánya, vagy Pilegaard 1997-es zsargonelemzése), vagy

- egyes szövegszintű jelenségek vizsgálatában (pl. Pisanski Peterlin (2008) metadiskurzus-elemzése, vagy Williams $(2004,2006,2007)$ téma-réma relációkat feltáró munkái; de ide sorolható Baker (1993) és Kemppanen (2004) tanulmánya is).

Nagy előnye a korpuszelemző szoftverek alkalmazásának, hogy nagyméretű korpuszon teszik lehetővé (géppel kereshető) jelenségek megbízható mennyiségi/gyakorisági vizsgálatát, $\mathrm{s}$ ez által általánosítható következtetések megfogalmazását. 
A korpusznyelvészeti szempontú vizsgálódások mellett azonban a tudományos szövegek fordítási sajátosságainak feltárásában számos egyéb, a kvantitatív természetủ megközelítések mellett a kvalitatív, feltáró, mélyreható elemzést lehetővé tevő módszerre is van szükség. Kézi szövegelemzéssel dolgoznak azok a kutatók, akik kisebb korpuszon olyan jelenségeket vizsgálnak (pl. logikai relációkat, müfaji szerkezetet, stilisztikai jegyeket), amelyeket számítógép nem tud azonosítani. Ilyen esetekben, mivel a vizsgált változók azonosítása az elemző szubjektív/intuitív megítélésén múlik, az elemzés megbízhatóságát kontrollelemzéssel lehet biztosítani. Ez történhet egy másik elemzö/kódoló bevonásával, vagy - bizonyos idő elteltével - az elemzés/kódolás újbóli elvégzésével, majd a két elemzés eredményeinek összevetésével (erről bővebben ld.: 3. rész). Kézi szövegelemzés eredményei olvashatók Götz Andrea (2015) tanulmányában, melyben a tudományos absztrakt müfaj fordításának sajátosságait tárja fel Swales 1990-es és Hyland 2004-es elemzési modellje segítségével. Szintén szövegszempontú munka Baumgarten, House és Probst (2004) cikke, ami fordított és eredeti (nem fordítás eredményeként létrejött) népszerü tudományos szövegeket elemez House 1997-es szisztémikus-funkcionális fordításértékelő modellje felhasználásával.

Fontos megjegyezni azonban, hogy a szövegtudomány elméleteinek és modelljeinek felhasználásával olyan jelenségek/változók is kutathatók eredeti és fordított szövegekben, amelyeket képes számítógép is azonosítani (ilyenek pl. a lexikai ismétlés vagy bizonyos grammatikai kohéziós eszközök). Így lehetővé válik, nagyméretü adatbázison, ezekre a jelenségekre vonatkozóan hipotézisek igazolása vagy cáfolata. Ezzel a gépi keresési módszerrel dolgozott Kemppanen is, a 2004es tanulmányában. A kulcsszó fogalmát Firth szerint értelmezve (mint "szociológiailag fontos" és “ideológiailag funkcionális" szó) egy olyan számítógépes alkalmazással dolgozott, mellyel egy-egy szó (pl. a finn 'barátság’/‘ystävyys' szó) fordítási viselkedésével kapcsolatos hipotéziseket tudott tesztelni.

A gépi vagy kézi szövegelemzések mellett a tudományos szakfordítás területén jelentős azon vizsgálódások köre, amelyek feltáró jellegü kvalitatív interjúkkal dolgoznak. Az interjúk során fordítókkal, szerzőkkel, könyv- vagy folyóirat szerkesztőkkel vesznek fel adatot. Az interjúk jól kiegészítik az eredmény-orientált (szövegelemző) vizsgálatokat, mert rávilágíthatnak a jelenségek okára is. MuñozMiquel (2014, idézi Muňoz-Miquel 2018: 28) például 12 orvosi szakfordítóval készített interjút, akik közül hét nyelvész, öt pedig orvos végzettségű szabadúszó, illetve valamilyen intézményhez kötődő szakember.

Az interjú-kutatások másik fajtája, ami szintén gyakori a területen, a fókuszcsoportos interjú. Brøgger például, 2017-es kvalitatív tanulmányában orvosi szakfordítók egy csoportját vizsgálja abból a szempontból, hogy ők milyen okok, illetve logika mentén hoznak döntéseket fordítás során. Eszközválasztását azzal indokolja, hogy az ilyen csoportos interjúkkal kevésbé kontrolált módon jut adathoz, valamint értékes információkat szerez azáltal is, hogy a beszélgetés során az interjúalanyoknak lehetőségük van egymás meglátásaira reagálni. A csoportos beszélgetéssel jelentősen csökkenthető a kutatói befolyás is. 
A kvantitatív/statisztikai vizsgálatok egyik leggyakoribb módszere a kérdőíves felmérés. Muňoz-Miquel 2018-as kutatásának adatgyűjtő eszköze például egy olyan online kérdőív, melyet az ún. LimeSurvey kérdőívező rendszer segítségével alakított ki. Ennek a rendszernek segítségével biztosítható a válaszok névtelensége és korlátozható a kérdőív kitöltésére jogosultak köre (csak jelszóval léphetnek be). Így megelőzhető nem csak az, hogy olyanok kitöltsék, akik nem felelnek meg a résztvevők kiválasztása során alkalmazott kritériumoknak, hanem az is, hogy valaki a kérdőívet egynél többször töltse ki (2018: 28).

A tudományos szakfordítás kutatása területén is találunk kísérleteket. A kísérleti módszert általában bizonyos képzési programok/eljárások eredményességének vizsgálatára (pl. Bowker (2016) a "speed training" nevü módszert próbálta ki a tudományos és műszaki szakfordító-képzésben) vagy egyes fordítói stratégiák/ döntések alaposabb megértése érdekében alkalmazzák. Ez utóbbira jó példa Farahzad (2003) kutatása, aki arra a kérdésre keresett választ, hogy az angol-perzsa fordítók hogyan és miért manipulálják fordítás során a szövegeket, és hogy a legfontosabb manipulatív eltolódások mögött milyen okok állnak. A kísérletben 20 fordító vett részt. Először egy fordítási feladatot kellett elvégezniük, majd ezt követően a szerző interjút készített velük.

Nem ritka az sem, amikor kvantitatív és kísérleti módszerekkel egyszerre dolgozik a kutató. Jimenez Crespo (2018) korpusz-alapú és feltáró/kvalitatív eszközöket is alkalmaz. Korpuszelemzését egy olyan kísérleti tanulmánnyal egészíti ki, amellyel angolról spanyolra fordított szövegeket tartalmazó orvosi honlapok befogadói megítélését, befogadhatóságát vizsgálta az Egyesült Államokban. Mérőeszközei kidolgozásakor felhasználta a korpuszelemzésből nyert adatokat is.

\section{A hitelesség és a megbízhatóság biztosítása a korpusz-alapú kutatásokban}

A fentiekben említett példák általában különféle kommunikációs helyzetekben dolgozó fordítók és szerzők szövegeit hasonlítják össze. Az összevetés tárgya többnyire a forrás- és a célnyelvi szöveg és/vagy a fordított (célnyelvi) és a nem fordítás eredményeként létrejött (eredetileg azon a nyelven írt) szöveg. Minden esetben fontos tényező a kutatás megtervezésénél a hitelesség (más szóval: érvényesség vagy validitás) és a megbízhatóság.

A kutatás abban az esetben teljesíti a hitelesség feltételét, ,ha valóban azt a jelenséget vizsgálja, amelyet eredetileg vizsgálni kívánt. Szövegelemzés esetében ez annyit jelent, hogy meg kell bizonyosodnunk arról, hogy a kidolgozott vagy alkalmazott elemzési modell alkalmas-e a vizsgálni kívánt jelenség elemzésére, illetve lefedi-e annak minden aspektusát" (Károly 2007: 253). Előfordulhat ugyanis, hogy egy adott nyelven és müfajban létező szövegfajta elemzésére kidolgozott modell vagy taxonómia nem alkalmazható egy az egyben más nyelven íródott vagy 
más müfajú szövegekre (pl. Hoey 1991-es ismétlésmodellje, amely nem alkalmazható narratív típusú szövegek elemzésére). Ilyen esetekben másik modellre, vagy a kérdéses modell módosítására van szükség. A hitelességnek különböző típusai vannak: tartalmi, fogalmi, egyezésen alapuló és elörejelző. Ezeket Brown (1988) részletesen tárgyalja, ezért itt nem térek ki rájuk.

A kutatás megbízhatósága azt jelenti, hogy ,azt megismételve - ugyanazon körülmények között - ugyanazt az eredményt kapjuk" (Károly 2007: 254). A megbízhatóság különösen a kézi szövegelemzés esetében kérdőjelezhető meg, ha a vizsgált változók azonosítása az elemző értelmezésén múlik. Megbízhatóságra és következetességre kell törekedni mind az adatgyüjtés, mind az adatelemzés során. Ennek egyik módja az adatgyüjtésben illetve elemzésben részt vevők képzése, „betanítása” arra, hogy a szakterminusokat (pl. az elemzési modell vagy taxonómia különböző kategóriáit, szempontjait) egységesen értelmezzék, az adatgyüjtés és adatelemzés kritériumait rutinosan alkalmazzák, és hasonlóan járjanak el a felmerülő problémákkal kapcsolatosan. Ez elengedhetetlen feltétele a korábbiakban említett kontrollelemzéseknek is, amikor általában legalább ketten - egymástól függetlenül - elemzik a szövegeket adott kritériumok alapján, majd egyeztetik eredményeiket. Az eltéréseket megvitatják, hogy megegyezésre jussanak, vagy ha ez nem sikerül, egy harmadik elemzőt kérnek fel arra, hogy eldöntse a vitát. Nagyméretű adatbázis esetében elegendő, ha a második elemző a szöveg egy részén végzi el az elemzést, majd ezt vetik össze az első elemzés eredményeivel. Ha egyeznek, nem szükséges tovább folytatni az ellenőrzést. Amennyiben a kutatónak nem áll módjában másik elemzőt alkalmazni, akkor saját maga is elvégezheti a második (kontroll) kódolást. Ilyenkor azonban meg kell várni, hogy a két kódolás között teljen el bizonyos mennyiségü idő, hogy az elemző „elfelejthesse” az első kódolás részleteit, és a második elemzéskor hozott döntéseit azok ne befolyásolják (Károly 2007: 254).

Mindezekből kiindulva elsőként Chesterman (1998: 54) modellezte a kontrasztív funkcionális elemzések menetét, amely alapján később Williams (2004) megalkotta az ún. célnyelvre orientált (korpusz-alapú) kontrasztív elemzési modellt. E modell szerint a célnyelvre orientált (korpusz-alapú) kontrasztív elemzések három fö lépésből állnak:

(1) nyelvi adatok gyüjtése (ez jelentheti a teljes korpusz összeállítását, vagy abból bizonyos részek kiemelését az elemzéshez);

(2) az összehasonlítási szempontok megadása, a nyelvi változók azonosítása, definiálása és statisztikai elemzése alapadatok nyerése céljából;

(3) kontextuális elemzés elkészítése.

A modell (Williams 2004: 72) a kontrasztív elemzések folyamatát összesen hét részelemre bontja: 
(1) elsődleges adat: egy három részből álló, összevethető szövegeket tartalmazó korpusz (anyanyelvi szövegek, fordítások ugyanezen a nyelven, eredeti referenciaszövegek);

(2) elemzési keret: összevethetőségi kritérium a kvantitatív elemzéshez (a célnyelvi változók meghatározása a fordítások és az anyanyelvi szövegek statisztikai összevetéséhez);

(3) probléma: kutatási kérdés (hogyan viszonyulnak a fordítások a célnyelvi statisztikai normákhoz?);

(4) nullhipotézis: mindkét minta ugyanattól a populációtól származik;

(5) statisztikai elemzés: a nullhipotézis elvetése ( $\mathrm{P}<0,05$ szinten);

(6) kvalitatív kontextuális elemzés a nullhipotézis elvetését követően: milyen kritériumokat alkalmaztak az anyanyelvi szövegekben; milyen kritériumokat alkalmaztak a fordításokban; milyen stratégiákkal lehet megszüntetni a különbségeket?

(7) újbóli statisztikai elemzés (ugyanazon statisztikai eljárásokkal): a célkritériumok és stratégiák alkalmazását követően a fordításban, az átdolgozott minta összevetése az anyanyelvi szöveggel és a fordításokkal.

Williams (2004) vizsgálatai arra engednek következtetni, hogy a kellő méretű korpuszokon elvégzett célnyelvre orientált kvantitatív összehasonlító elemzések - empirikus adattartalmuk és a fordítás folyamatáról nyújtott információk révén - olyan jelentős eredményekkel bővítik a fordítással kapcsolatos ismereteinket, melyek később haszonnal alkalmazhatók nem csupán a fordítóképzésben, hanem a fordítás gyakorlatában is.

A kutatás megbízhatósága és hitelessége szempontjából az elemzéshez választott korpusz kulcsfontosságú. A korpusz alapú vizsgálatok ezért kiemelt figyelmet kell, hogy szenteljenek a korpuszépítés mikéntjeire és a korpuszépítési szempontok körültekintő, a vizsgálat célját szem előtt tartó meghatározására. Jó példa erre az a kritériumrendszer, melyet Krein-Kühle (2011: 392-396) tanulmánya mutat be részletesen a Cologne Specialized Translation Corpus projekt kapcsán, vagy López-Arroyo és Roberts (2017) az összehasonlító korpuszok vonatkozásában. López-Arroyo és Roberts (2017: 115) szerint a nyelvek közötti összevetésekhez többnyelvü, reprezentatív korpuszokra van szükség: párhuzamos korpuszra (forrásnyelvi szövegekböl és célnyelvi változataikból), vagy összehasonlító korpuszra (ami két vagy több nyelven tartalmaz szövegeket). Felhívják ugyanakkor a figyelmet arra, hogy még az sem jelent feltétlenül garanciát a különféle nyelvü szövegeket tartalmazó korpuszok összevethetőségére, ha minden alapvető korpuszépítési szempontot figyelembe veszünk: a szövegek arányát, müfaját, témáját és keletkezésük idejét (McEnery és Xiao 2007: 20, idézi López-Arroyo és Roberts 2017: 115).

Különféle szövegmüfajokon végzett elemzéseik alapján, az angol és a spanyol nyelvböl kiindulva arra mutattak rá, hogy még ha elöre meghatározott, majd a későbbiekben tovább finomított szövegválasztási kritériumokkal dolgozunk is, előfordulhat, hogy a különféle nyelveken született azonos müfajú szakszövegek 
sem mutatnak kellő hasonlóságot (müfaji) szempontból. Míg ugyanis a tudományos absztraktokon végzett vizsgálataik alapján a különböző nyelvü absztraktokat tartalmazó korpuszaik összevethetőnek bizonyultak, ugyanezt a borkóstoló jegyzetekből álló másik korpuszukról nem mondhatták el, mert regisztertulajdonságaik tekintetében az angol és a spanyol szövegek eltértek egymástól (2017: 114-116). Egy összehasonlító korpusz akkor ad megbízható eredményt, ha a benne levő különböző nyelvü szövegek egyszerre több szinten mutatnak hasonlóságot. Tapasztalataik szerint a müfaji azonosság önmagában nem garantálja a korpuszok összevethetőségét, a regiszterbeli egyezés legalább olyan fontos. Ha ugyanis az összehasonlító korpusz nem minden szempontból összevethető szövegeket tartalmaz, akkor a benne levő (látszólagos) lexikai vagy strukturális ekvivalenciák megbízhatósága megkérdőjelezhető és megerősítésre, bizonyításra szorul, más adatok alapján (2017: 129).

Baumgarten, House és Probst (2004: 68) ezért már három korpusszal dolgozik: egy fordítási, egy összehasonlító és egy ún. validációs (hitelesítö) korpusszal. Fordítási korpuszuk eredeti angol szövegeket és azok német fordításait tartalmazza, az összehasonlító korpusz angol és német eredeti (nem fordítás útján keletkezett), azonos múfajú és hasonló témájú szövegeket, a validációs korpusz pedig szintén fordításokból áll, de ellentétes irányban: ugyanazon müfajú szövegek németről angolra, valamint angolról franciára és spanyolra készült fordításaiból. A validációs korpusz létrehozásának célja a fordítási és az összehasonlító korpusz szövegeinek elemzéséből nyert eredmények validálása/hitelesítése.

\section{4. Összegzés}

Korszerü felfogásban ,„a fordítási szöveget nem statikus produktumként, hanem egy dinamikusan változó kulturális kontextus funkcionális elemeként fogjuk fel" (Károly 2007: 252). Ezért kérdőjelezhető meg a fordítás csupán szöveg-alapú vizsgálatának létjogosultsága, mivel a szövegelemzés elsősorban leíró jellegü következtetésekre nyújt lehetőséget, a jelenségek okairól nem sokat árul el. A fentiekből jól látható, hogy a fordítási jelenségek okainak feltárására egyéb eszközökre is szükség van (interjúkra, kérdőívekre, kísérletekre stb.), amelyek betekintést engednek a fordítás módszerét és jellegét meghatározó kontextus, a fordító, a célközönség stb. sajátosságaiba is. A tudományos szakfordítás területén végzett empirikus kutatások módszertani sokszínűsége és gazdagsága ennek jelentőségét méltóképpen illusztrálja. Dolgozatom második felében a fordítási szöveg elemzéséhez szükséges korpusz összeállításának kockázataira és ezek lehetséges kezelési módjaira tettem javaslatot a tudományos szaknyelvi fordítás kutatásának területéről vett példák felhasználásával.

A bemutatott eljárások révén olyan újszerü eredmények birtokába juthatunk, amelyek segítségével mára leírhatóvá vált a tudományos szakfordítás számos törvényszerüsége és a szakfordító föbb tulajdonságai. Empirikus eredmények külön- 
féle nyelvpárok, tudományos/felsőoktatási müfajok (pl. monográfia, szakcikk, absztrakt, tankönyv, szakdolgozat) és diszciplínák (pl. orvostudomány, gazdaságtudomány, bölcsészettudomány, ill. azon belül is különösen az irodalom- és kultúratudomány, a filozófia, a történelemtudomány stb.) terén születtek (ezekröl bővebben ld.: Károly megjelenés alatt). Néhány kivételtő eltekintve (pl. Albert 2000, 2001, Götz 2015, Heltai 2008) azonban sajnálatosan kevés a magyar vonatkozású kutatások száma a területen. Annak ellenére van ez így, hogy a tudományos fordítási tevékenység (különösen az angol nyelvre történő fordítás) - a szó legtágabb értelmében, amely magába foglalja a nyelvek közötti fordítást épp úgy, mint az önfordítást és a szöveg célnyelven/angolul történő megírását (Károly 2019: 10-11) - a hazai tudományos élet nemzetközi versenyképességének és ismertségének egyik legfontosabb eszköze.

\section{Irodalom}

Albert S. 2000. Filozófiai szövegek fordítása 1. rész. Fordítástudomány 2. évf. 2. szám. 2. $5-23$.

Albert S. 2001. Filozófiai szövegek fordítása 2. rész Fordítástudomány 3. évf. 1. szám. $5-25$.

Baker, M. 1993. Corpus Linguistics and Translation Studies. Implications and Applications. In: Baker, M. Francis, G. Tognini-Bonelli, E. (eds) Text and Technology. In Honour of John Sinclair. Amsterdam/Philadelphia: John Benjamins. 233-250. https:// doi.org/10.1075/z.64.15bak

Baumgarten, N., House, J., Probst, J. 2004. English as a Lingua Franca in Covert Translation Processes. The Translator Vol. 10. No. 1. 83-108. https://doi.org/10.1080/1355 6509.2004.10799169

Bowker, L. 2016. The Need for Speed! Experimenting with "Speed Training" in the Scientific/Technical Translation Classroom. Meta Vol. 61(Hors série). 22-36. https://doi. org/10.7202/1038683ar

Brown, J. D. 1988. Understanding Research in Second Language Learning. Cambridge: Cambridge University Press.

Brøgger, M. N. 2017. When Translation Competence is Not Enough: A Focus Group Study of Medical Translators. Meta Vol. 62. No. 2. 397-414. https://doi.org/10.7202/1041030ar

Chesterman, A. 1998. Causes, Translations, Effects. Target Vol. 10. No. 2. 201-230. https:// doi.org/10.1075/target.10.2.02che

Creswell, J. W. 2009. Research Design - Qualitative, Quantitative, and Mixed Methods Approaches. ( $3^{\text {rd }}$ ed.). Thousand Oaks: Sage.

Denzin, N., Lincoln, Y. 1994/2000. Handbook of Qualitative Research. Thousand Oaks: Sage.

Farahzad, F. 2003. Manipulation in Translation. Perspectives: Studies in Translatology Vol. 11. No. 4. 269-281. https://doi.org/10.1080/0907676x.2003.9961480

Fuertes-Olivera, P. A., Pizarro-Sánchez, I. 2002. Translation and 'Similarity-creating Metaphors' in Specialized Languages. Target Vol. 14. No. 1. 43-73. https://doi. org/10.1075/target.14.1.03fue 
Götz A. 2015. Magyar és angol absztraktok retorikai szerkezetének elemzése. Forditástudomány 17. évf. 2.szám. 88-116.

Heltai P. 2008. Lexikai átváltási müveletek irodalmi és szakfordításban. Forditástudomány 10. évf. 1. szám. 5-17.

Hoey, M. 1991. Patterns of Lexis in Text. Oxford: Oxford University Press.

House, J. 1997. Translation Quality Assessment. A Model Revisited. Tübingen: Narr.

Hyland, K. 2004. Genre and Second Language Writing. Ann Arbor: The University of Michigan Press. https://doi.org/10.3998/mpub.23927

Jawad, H. A. 2014. Shifts in Translating Jeremy Munday into Arabic: Asymmetric Explicitation. Across Languages and Cultures Vol. 15. No. 1. 51-66. https://doi. org/10.1556/acr.15.2014.1.3

Jiménez-Crespo, M. A. 2018. Combining Corpus and Experimental Studies: Insights into the Reception of Translated Medical Texts. The Journal of Specialized Translation Vol. 28. (2018 July).

Károly K. 2007. Szövegtan és fordítás. Budapest: Akadémiai Kiadó.

Károly K. 2019. Tudományfordításról fordítástudományi megközelítésben. Forditástudomány 21. évf. 2. szám. 2. 5-16.

Károly K. megjelenés alatt. Translating Academic Texts. In: Malmkjær, K. (ed.) The Cambridge Handbook of Translation. Cambridge: Cambridge University Press.

Kemppanen, H. 2004. Keywords and Ideology in Translated History Texts: A Corpusbased Analysis. Across Languages and Cultures Vol. 5. No. 1. 89-106. https://doi. org/10.1556/acr.5.2004.1.5

Klaudy, K. 2007. Hipotézisalkotás a fordítástudományban. In: Klaudy K. (szerk.) Nyelv és forditás. Válogatott fordítástudományi tanulmányok. Budapest: Tinta Könyvkiadó. 207-213.

Krein-Khüle, M. 2011. Register Shifts in Scientific and Technical Translation. A Corpusin-context Study. The Translator Vol. 17. No. 2. 391-414. https://doi.org/10.1080/135 56509.2011.10799495

López-Arroyo, B., Méndez-Cendón, B. 2007. Describing Phraseological Devices in Medical Abstracts: An English/Spanish Contrastive Analysis. Meta Vol. 52. No. 3. 503-516. https://doi.org/10.7202/016735ar

López-Arroyo, B., Roberts, R. P. 2017. Genre and Register in Comparable Corpora: An English/Spanish Contrastive Analysis. Meta Vol. 62. No. 1. 115-136. https://doi. org/10.7202/1040469ar

Muňoz-Miquel, A. 2018. Differences Between Linguists and Subject-matter Experts in the Medical Translation Practice. An Empirical Descriptive Study with Professional Translators. Target Vol. 30. No. 1. 24-52. https://doi.org/10.1075/target.14130.mun

Pilegaard, M. 1997. Translation of Medical Research Articles. In: Trosborg, A. (ed.) Text Typology and Translation. Amsterdam, Philadelphia: John Benjamins. 159-184.

Pisanski Peterlin, A. 2008. Translating Metadiscourse in Research Articles. Across Languages and Cultures Vol. 9. No. 2. 205-218. https://doi.org/10.1556/acr.9.2008.2.3

Swales, J. M. 1990. Genre Analysis. English Academic and Research Settings. Cambridge: Cambridge University Press.

Toury, G. 1995. Descriptive Translation Studies and Beyond. Amsterdam, Philadelphia: John Benjamins. 
Williams, I. A. 2004. How to Manage Patients in English-Spanish Translation: A Targetoriented Contrastive Approach to Methods. Target Vol. 16. No. 1. 69-103. https://doi. org/10.1075/target.16.1.05wil

Williams, I. A. 2006. Towards a target-oriented model of quantitative contrastive analysis in translation studies: an exploratory study of theme-rheme structure in SpanishEnglish biomedical research articles. Languages in Contrast Vol. 6. No. 1. 1-45. https://doi.org/10.1075/lic.6.1.02wil

Williams, I. A. 2007. A corpus-based study of the verb observer in English-Spanish translations of biomedical research articles. Target Vol. 19. No. 1. 85-103. https://doi. org/10.1075/target.19.1.06wil

Williams, J., Chesterman, A. 2002. The Map. A Beginner's Guide to Doing Research in Translation Studies. Manchester: St. Jerome. 